\title{
Clinical efficacy of 9-oxo-10, 11-dehydroageraphorone extracted from Eupatorium adenophorum against Psoroptes cuniculi in rabbits
}

Yang $\mathrm{Hu}^{1 \dagger}$, Fei Liao ${ }^{1,2+}$, Yanchun Hu*, Biao Luo ${ }^{1}$, Yajun $\mathrm{He}^{1}$, Quan Mo ${ }^{1}$, Zhicai Zuo ${ }^{1}$, Zhihua Ren', Junliang Deng ${ }^{1}$ and Yahui Wei ${ }^{3}$

\begin{abstract}
Background: Animal acariasis is one of the important veterinary skin diseases. Chemical drugs have been widely used to treat and control this kind of disease. But many chemicals control could increase resistance in target species, toxicity and environmental hazards. We found that the 9-oxo-10, 11-dehydroageraphorone (euptox A) extracted from E. adenophorum has strong toxicity against $P$. cuniculi in vitro, but the in vivo acaricidal actions of euptox A have yet to be investigated.

Results: A 14-day experiment was performed using rabbits that were naturally infested with $P$. cuniculi on a farm. Rabbits were randomly divided into five groups; animals in groups $A, B$ and $C$ were treated in each ear topically with $4.0 \mathrm{ml}$ of 2.0 and $1.0 \mathrm{~g} / \mathrm{L}(\mathrm{W} / \mathrm{v})$ euptox A, respectively. Animals in groups $D$ and $E$ were treated with ivermectin (by injection; positive controls) and glycerol with water only (by embrocation; negative controls), respectively. Each rabbit was treated twice with separate treatments on days 0 and 7 . Rabbits were observed daily and detailed examinations were performed on days 0,7 and 14, to inspect the presence or absence of mites and scabs/crusts. Seven days after the initial treatment, the mean clinical scores (presence of scabs/crusts) decreased from 3.48, 3.37, 3.43 and 3.45 to 0.37, $0.42,0.78$ and 0.38 in the ears of animals in groups $A, B, C$ and $D$, respectively, which were similar to the observations recorded in the positive control rabbits. However, the clinical score for negative control rabbits did not increase significantly $(P>0.05)$ during the experiment, and this changed from 3.32 to 3.37 in the ears, and there were no significant differences in clinical efficacy between left and right ears. After two treatments ( 0 and $7 \mathrm{~d}$ ), the rabbits in groups A, B, C and D had recovered completely 14 days after the last treatment and no recurrences of infection were observed.
\end{abstract}

Conclusions: These results indicate that euptox A was potent compounds for the effective control of animal P. cuniculi in vivo.

Keywords: Euptox A, Eupatorium adenophorum, Psoroptes cuniculi, Acaricidal, Clinical efficacy

\footnotetext{
* Correspondence: yanchunhu@126.com

${ }^{\dagger}$ Equal contributors

${ }^{1}$ Key laboratory of Animal Disease and Human Health of Sichuan Province, College of Veterinary, Medicine, Sichuan Agricultural University, Sichuan Province, Ya an 625014, China

Full list of author information is available at the end of the article
} 


\section{Background}

Animal acariasis, an important veterinary diseases, may reduce the productivity and the quality of animal products, even lead to death [1]. At present, chemical drugs are widely used to treat and control the psoroptes and sarcoptic mange in veterinary clinic, and obtained the relative good treatment effectiveness, including ivermectin, and abamectin, etc. But the chemical control could increase resistance in target species, toxicity and environmental hazards [2].

A large number of reports have indicated that the secondary metabolites synthesized and accumulated in Eupatorium adenophorum (E. adenophorum) have wide biological activities. For example, there are reports of chronic respiratory disease and exercise intolerance in horses in Australia due to ingestion of E. adenophorum [3]. The ethanol extract from leaves of E. adenophorum were anti-Inflammatory potential [4], acaricidal activity [5,6], antioxidant activity [7], and other extract form $E$. adenophorum torium had toxic activity against Oncomelania hupensis, the intermediate host snail of Schistosoma japonicum [8], Tinea [9] and Aphis gossypii [10]. The acetone extract of $E$. adenophorum had strong toxicity against Cabbage aphids and Brevicoryne brassicae [11].

9-oxo-10, 11-dehydroageraphorone (euptox A), is the main toxin extracted from E. adenophorum [12,13]. Euptox A takes a large proportion of E. adenophorum toxins $[14,15]$, can cause not only the allergic bronchial pneumonia of horses which is characterized by pulmonary interstitial fibrosis, emphysema, alveolar epithelisation and reduced tolerance to exercise $[3,16]$, but the contact dermatitis of other domestics animals like cattle and goats [17]. Furthermore, according to some studies, for mice, lesions occur in the liver. The hepatic injury in these animals is characterised by multiple areas of focal necrosis of the parenchyma associated with degeneration and loss of the epithelium lining the small bile ducts $[18,19]$. Euptox A belongs to a cadenine sesquiterpene. A large number of reports indicated that the cadenine sesquiterpene has wide biological activities such as antitumor activity [20],

\section{Table 1 Parameters used to evaluate the clinical score of} infection and degree of recovery

\begin{tabular}{ll}
\hline Infection and degree of recovery & $\begin{array}{l}\text { Clinical } \\
\text { score }\end{array}$ \\
\hline Absence of scabs and/or mites & 0 \\
Irritation in ear canal but no mites observed & 0.5 \\
Small number of scabs in the ear canal, mites present & 1 \\
External ear canal filled with scabs, mites present & 2 \\
Scabs in ear canal and proximal 1/4 of pinna, mites present & 3 \\
1/2 pinna filled with scabs, mites present & 4 \\
$3 / 4$ of the pinna filled with scabs, mites present & 5 \\
All internal surface of the pinna full of scabs, mites present & 6 \\
\hline
\end{tabular}

Table 2 The clinical score of infection and degree of the recovery from infection of the external ear margins in rabbits (mean \pm standard error)

\begin{tabular}{llllll}
\hline Day & Group A & Group B & Group C & Group D & Group E \\
\hline 0 & $3.48 \pm$ & $3.37 \pm$ & $3.43 \pm$ & $3.45 \pm$ & $3.23 \pm$ \\
& $0.27 \mathrm{~A}(\mathrm{~A})$ & $0.21 \mathrm{~A}(\mathrm{~A})$ & $0.22 \mathrm{~A}(\mathrm{~A})$ & $0.23 \mathrm{~A}(\mathrm{~A})$ & $0.21 \mathrm{~A}(\mathrm{~A})$ \\
7 & $0.37 \pm$ & $0.42 \pm$ & $0.78 \pm$ & $0.38 \pm$ & $3.37 \pm$ \\
& $0.19 \mathrm{~B}(\mathrm{~B})$ & $0.17 \mathrm{~B}(\mathrm{~B})$ & $0.15 \mathrm{C}(\mathrm{B})$ & $0.15 \mathrm{~B}(\mathrm{~B})$ & $0.23 \mathrm{~A}(\mathrm{~A})$ \\
14 & $0.00 \pm$ & $0.00 \pm$ & $0.00 \pm$ & $0.00 \pm$ & $3.45 \pm$ \\
& $0.00 \mathrm{~B}(\mathrm{C})$ & $0.00 \mathrm{~B}(\mathrm{C})$ & $0.00 \mathrm{~B}(\mathrm{C})$ & $.0 .00 \mathrm{~B}(\mathrm{C})$ & $0.23 \mathrm{~A}(\mathrm{~A})$ \\
\hline
\end{tabular}

Note: The different letters within a row denote significant differences between the difference groups $(P<0.05)$. The numbers in brackets represent the clinical therapeutic efficacy in accordance with the calculation of the decrease of the mites. The different letters in brackets within a column denote significant differences between the different treatment days $(P<0.05)$.

antigerminative activity [21], neurotrophic activity [22], larvicidal activity [23], antiprotozoal activity [24], and so on. Euptox A was found highly active against the fast growing A549, Hela and Hep-2, and its activity was concentration-dependent [25]. In a previous study, euptox A exhibited strong toxicity against S. scabiei and P. cuniculi in vitro [26], but the in vivo acaricidal actions of euptox A have yet to be investigated.

Thus, the aim of this present study was to assess the clinical acaricidal efficacy of euptox A against P. cuniculi in rabbits in vivo.

\section{Methods}

\section{Extraction and purification of euptox $A$}

E. adenophorum was collected from Xichang City (102 ${ }^{\circ}$ $30222^{\prime}$ E, $27^{\circ} 873213^{\prime} S$ ) of Sichuan Province, Southwest China in July, 2012. Euptox A was extraction from $E$. adenophorum by the Key laboratory of Animal Disease and Human Health of Sichuan Agricultural University, China [25-27].

\section{Experimental animals}

Thirty rabbits that were naturally infected with P.cuniculi were obtained from a farm affected by an outbreak. All the animals were of similar age, weight and clinical score (in terms of the presence/absence of scabs and crusts). In all 30 rabbits, there were no significant difference between the level of infection in the ears, and had not been treated with acaricides and no other infectious diseases were known to be present. Sampling procedures adhered to institutional ethical and animal care guidelines and all methods were conducted in accordance with the Guide for the Care and Use of Laboratory Animals adopted and promulgated by the United National Institutes of health. All experimental protocols were approved by review committee for the use of human or animal subjects of College of veterinary medicine, Sichuan Agricultural University. 


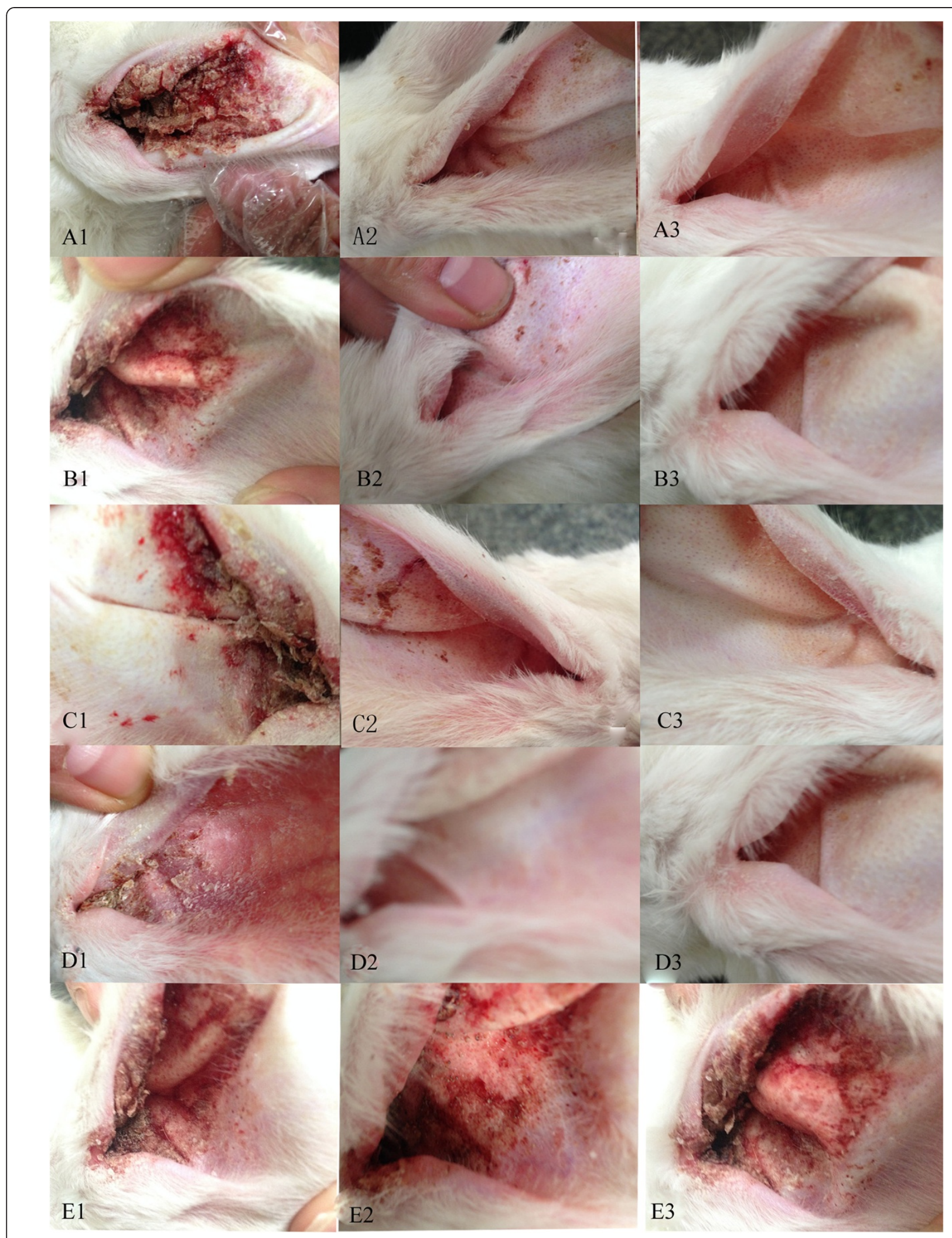

Figure 1 Clinical observations of rabbits treated with euptox A against $P$. cuniculi. (A)-(E) denote rabbits that were treated with euptox $A$ at 4, 2, $1 \mathrm{mg} / \mathrm{ml}$, ivermectin and glycerol and water only, respectively. A1, B1, C1, D1 and E1 show the signs of infection before treatment; A2, B2, $C 2, D 1$ and $E 1$ show the observations at day 7; and A3, B3, C3, D1 and E1 show the observations at day 14 . 


\section{Acaricidal activity in vivo}

The euptox A was diluted from the concentration of 4 $\mathrm{mg} / \mathrm{ml}$ to $1 \mathrm{mg} / \mathrm{ml}(4 \mathrm{mg} / \mathrm{ml}, 2 \mathrm{mg} / \mathrm{ml}$ and $1 \mathrm{mg} / \mathrm{ml})$ in $10 \%$ glycerin.

The experimental procedures were performed as described previously by [28]. The thirty rabbits were divided into five equal groups at random (groups A, B, C, $\mathrm{D}$ and $\mathrm{E})$. Groups $\mathrm{A}, \mathrm{B}$ and $\mathrm{C}$ were treated at days 0 and 7 with 4,2 and $1 \mathrm{mg} / \mathrm{ml}$ of euptox A, respectively. Groups D and E were treated twice with ivermectin (by injection $200 \mu \mathrm{g} / \mathrm{kg}$ ) and glycerol and water only (by embrocation) as the positive and untreated control groups, respectively. In the treatment process, each of the left and right ears were treated with the use of a cotton swab dipped with $2 \mathrm{ml}$ of the euptox A, then embrocated treatment as an ointment. The presence of clinical signs was assessed daily and any abnormal reactions were recorded. Detailed examinations were performed on days 0,7 and 14 which included an assessment of the presence or absence of mites and an evaluation of clinical infection and the degree of recovery. The criteria used to evaluate the clinical infection score and degree of recovery can be found in Table 1 [28].

\section{Statistical analysis}

Statistical analysis was performed using SPSS software (SPSS, version 20.0) [29] to assess the presence of statistically significant differences in infection and recovery scores, and therapeutic effects of different concentrations of euptox A and different treatment times. Significance values were corrected for with Duncan's multiple comparisons test [30].

\section{Results}

The criteria used to evaluate the clinical infection score and degree of recovery can be found in Table 1, The mean degree of infection was similar in each group at the start of the experiment and no significant differences were detected (Table 2).

All infected rabbits treated with 4,2 and $1 \mathrm{mg} / \mathrm{ml}$ of euptox A (groups A, B and C) recovered and were completely cured by day 14 (Figure $1 \mathrm{~A} 3, \mathrm{~B} 3$ and $\mathrm{C} 3$ ). In addition, the rabbits in group A-C with 4,2 and $1 \mathrm{mg} / \mathrm{ml}$ of euptox A displayed improved clinical signs during the experiment, although redness and inflammation were found in parts of the ear canals (Figure 1A2,B2 and C2). However, after the second treatment, the infected rabbits in group A-C were cured completely. Rabbits in group D (positive control) exhibited improvements in clinical signs during the experiment and no inflammation was observed (Figure 1D2 and D3). However, rabbits treated with negative control showed only minor signs of aggravated (Figure 1E2 and E3). After determining that there was no new crust formation after day 7 , and that there were no mites on otoscopic examination, we treated scabs topically with the relevant euptox A (A, B and C groups) or ivermectin (D group).

Mites were collected and burdens assessed to provide values for mite reduction and negative transformation rate (\%). From day 7 , no mites were present in the left or right ears of any rabbits in these groups (A, B and D group). In group $C$, there were small amount of mites. Compared with the negative control group, treatment with euptox A gave significant improvements in clinical signs at each time point. The rabbit itching mite negative transformation rate in treatment group (A-D) were up to $100 \% 14 \mathrm{~d}$ after treatment (Table 3), and there were not badness (not irritant to the skin and toxicity).

\section{Discussion}

Good clinical efficacy was achieved with the euptox A extract from $E$. adenophorum, against the scab mites, $P$. cuniculi. The clinical acaricidal efficacy of euptox A was similar to that of injectable ivermectin, and this observation is consistent with the euptox A has strong toxicity against S. scabiei and P. cuniculi in vitro [26], whilst consistent with petroleum ether extract form E.adenophorum against $P$. cuniculi in vitro [31]. The clinical acaricidal efficacy was showed to be time- and concentrationdependent, with the euptox A displaying similar effects to the alcohol extract from $E$. adenophorum against P. cuniculi. In the current study, the euptox A showed better clinical acaricidal efficacy $(2 \mathrm{ml} / \mathrm{ml})$ than the alcohol extract from E. adenophorum $(1 \mathrm{~g} / \mathrm{ml})$ [32], whilst the petroleum ether extract of neem oil comparatively weak bioactivity $\left(\mathrm{LC}_{50}, 500.0 \mathrm{ll} / \mathrm{ml}\right)$ [33].

E. adenophorum has been reported to have hepatotoxic effects in rodents $[15,34,35]$ which could limit its development as an acaricidal agent. But the acute toxicity test and skin hypersensitive test of euptox A had been finished, the euptox A were not irritant to the skin and toxicity of rabbits. Combining our previous results with this trial, we firmly believe that, euptox A shows a good clinical therapeutic effect on animal acariasis.

\begin{tabular}{|c|c|c|c|c|}
\hline Time & $0 \mathrm{~d}$ & $7 d$ & $14 \mathrm{~d}$ & $\begin{array}{l}\text { Negative } \\
\text { transformation } \\
\text { rate } \%\end{array}$ \\
\hline Group A & $24.33 \pm 1.97$ & $0.00 \pm 0.00$ & $0.00 \pm 0.00$ & 100.00 \\
\hline Group B & $21.50 \pm 2.17$ & $0.00 \pm 0.00$ & $0.00 \pm 0.00$ & 100.00 \\
\hline Group C & $18.61 \pm 2.17$ & $2.17 \pm 1.72$ & $0.00 \pm 0.00$ & 100.00 \\
\hline Group D & $24.61 \pm 2.07$ & $0.00 \pm 0.00$ & $0.00 \pm 0.00$ & 100.00 \\
\hline Group E & $19.83 \pm 2.13$ & $22.83 \pm 2.48$ & $24.00 \pm 2.37$ & -21.03 \\
\hline
\end{tabular}




\section{Conclusion}

We believe that, after further in-depth study, euptox A, a potent herbal drug, will be more widely applied in treatments for humans and animals. This study provides a new way for utilization of E. adenophorum and the euptox A has the potential as acaricidal drugs in livestock, and future possible scope of the product in small animal vet medicine, e.g. against Octodectes ear mites and other common ectoparasites of dogs and cats. But in order to make the research systematic, the mechanism of action has yet to be determined.

\section{Competing interests}

The authors declare that they have no competing interests.

\section{Authors' contributions}

YH performed the majority of the study and analyzed the data, FL contributed to drafting of the manuscript and partial acaricidal study. ZCZ, ZHR, JJD and YW provided technical assistance. $\mathrm{BL}, \mathrm{YJH}$ and QM contributed to partial acaricidal study and partial analyses of the data. YCH conceived and designated the study plan, participated in all aspects of the study, provided funds and supervised the research. All authors read and approved the final manuscript.

\section{Authors' information}

Yang $\mathrm{Hu}$ and Fei Liao should be considered as first authors.

\section{Acknowledgements}

This research was supported by Science and Technology Support Program of Sichuan Province (Grant No. 2015SZ0201), Special Fund for Agroscientific Research in the Public Interest (Grant No. 201203062) and Chang-jiang Scholars and the Innovative Research Team in University (Grant No. IRT0848).

\section{Author details}

${ }^{1}$ Key laboratory of Animal Disease and Human Health of Sichuan Province, College of Veterinary, Medicine, Sichuan Agricultural University, Sichuan Province, Ya an 625014, China. ${ }^{2}$ Qiandongnan Prefectural Center for Animal Disease Control and Prevention of Guizhou province, Kaili 556000, China. ${ }^{3}$ Key Laboratory of Resource Biology and Biotechnology in Western China, School of Life Science, Northwest University, Xi'an 710069, China.

Received: 8 August 2014 Accepted: 13 December 2014

Published online: 20 December 2014

\section{References}

1. Shang XF, Miao XL, Wang DS, Li JX, Wang XZ, Yan ZT, Wang CM, Wang Y, He XR, Hu P: Acaricidal activity of extracts from Adonis Coerulea Maxim. Against Psoroptes Cuniculi in vitro and in vivo. Vet Parasitol 2013, 195:136-141.

2. Borges FA, Almeida GD, Heckler RP, Lemes RT, Onizuka MK DGB: Anthelmintic resistance impact on tropical beef cattle productivity: effect on weight gain of weaned calves. Trop Anim Heal Pro 2013, 45:723-727.

3. O'sullivan B: Investigations into crofton weed (Eupatorium adenophorum) toxicity in horses. Aust Vet J 1985, 62(1):30-32.

4. Chakravarty AK, Mazumder T, Chatterjee SN: Anti-inflammatory potential of ethanolic leaf extract of Eupatorium adenophorum Spreng. Through Alteration in Production of TNF- $a$, ROS and expression of certain genes. Evid Based Complement Alternat Med 2011, doi:10.1093/ecam/neq033.

5. Nong X, Ren YJ, Wang JH, Xie Y, Fang CL, Yang DY: Clinical efficacy of botanical extracts from Eupatorium adenophorum against the Sarcoptes scabiei (Sarcoptidae: Sarcoptes) in Rabbits. Vet Parasitol 2013: doi.org/ 10.1016/j.vetpar.2013.1002.1020.

6. Seddiek SA, Khater HF, El-Shorbagy MM, Ali AM: The acaricidal efficacy of aqueous neem extract and ivermectin against Sarcoptes scabiei var. cuniculi in experimentally infested rabbits. Parasitol Res 2013, 112(6):2319-2330.

7. Kundu A, Saha S, Walia S, Ahluwalia V, Kaur C: Antioxidant potential of essential oil and cadinene sesquiterpenes of Eupatorium adenophorum. Toxicol Environ Chem 2013, 95(1):127-137.
8. Zou F, Duan G, Xie Y, Zhou Y, Dong G, Lin R, Zhu X: Molluscicidal activity of the plant Eupatorium adenophorum against Oncomelania hupensis, the intermediate host snail of Schistosoma japonicum. Ann Trop Med Parasitol 2009, 103(6):549-553.

9. Romero-Cerecero O, Zamilpa A, Jiménez-Ferrer E, Tortoriello J: Therapeutic effectiveness of Ageratina pichinchensis on the treatment of chronic interdigital Tinea Pedis: a randomized, double-blind clinical trial. J Alternative Compl Med 2012, 18(6):607-611.

10. Sun $X Y$, Lu ZH, Sang WG: Review on studies of Eupatorium adenophoruman important invasive species in China. J Forest Res 2004, 15(4):319-322.

11. Xu R, Wu D, Zhang W, Yin F, Kuang R: Efficacy of Ageratina adenophora extract and biogas fermentation residue against the cabbage aphid, Brevicoryne brassicae and an assessment of the risk to the Parasitoid diaeretiella rapae. Int J Pest Manag 2009, 55(2):151-156.

12. Seawright $A$, Oelrichs $P, N g$ J, Nolan $C$, Jukes $R$, Davis A: GSH-dependent biliary tract toxicity in the mouse caused by 9 -oxo-10, 11dehydroageraphorone (euptox). Toxicol Lett 1998, 95(1001):162-162.

13. He L, Hou J, Gan M, Shi J, Chantrapromma S, Fun H-K, Williams ID, Sung $\mathrm{HH}-\mathrm{Y}$ : Cadinane sesquiterpenes from the leaves of Eupatorium adenophorum. J Nat Prod 2008, 71(8):1485-1488.

14. Bohlmann F, Gupta RK: Six cadinene derivatives from Ageratina adenophora. Phytochemistry 1981, 20(6):1432-1433.

15. Kaushal V, Dawra R, Sharma O, Kurade N: Biochemical alterations in the blood plasma of rats associated with hepatotoxicity induced by Eupatorium adenophorum. Vet Res Commun 2001, 25(7):601-608.

16. Oelrichs PB, Calanasan CA, Macleod JK, Seawright AA, Ng JC: Isolation of a compound from Eupatorium adenophorum (Spreng.) [Ageratina adenophora (Spreng.)] causing hepatotoxicity in mice. Nat Toxins 1995, 3(5):350-354.

17. Bai J, Cao A, Guo M, Liu X, Liu X, Liang H, Zhou B: Identification of 9-oxo10,11-dehydroagerophorone in Eupatorium adenophorum by high performance liquid chromatography. Chin Bull Bot 2011, 46(4):470-475.

18. Bhardwaj R, Singh A, Sharma OP, Dawra RK, Kurade NP, Mahato SB: Hepatotoxicity and cholestasis in rats induced by the sesquiterpene, 9-oxo-10,11-dehydroageraphorone, isolated from Eupatorium adenophorum. J Biochem Mol Toxicol 2001, 15(5):279-286.

19. Katoch R, Sharma OP, Dawra RK, Kurade NP: Hepatotoxicity of Eupatorium adenophorum to rats. Toxicon 2000, 38(2):309-314.

20. Kikuchi T, Watanabe K, Tochigi Y, Yamamoto A, Fukatsu M, Ezaki Y, Tanaka R, Akihisa T: Melanogenesis inhibitory activity of sesquiterpenes from Canarium ovatum Resin in mouse B16 melanoma cells. Chem Biodivers 2012, 9(8):1500-1507.

21. Sv A, Langenfeld A, Blond A, Dupont J, Nay B, Prado S: Guaiane sesquiterpenes from Biscogniauxia nummularia featuring potent antigerminative activity. J Nat Prod 2012, 75(4):798-801.

22. Trzoss L, Xu J, Lacoske MH, Mobley WC, Theodorakis EA: Illicium sesquiterpenes: divergent synthetic strategy and neurotrophic activity studies. Chemistry 2013, 19(20):6398-6408.

23. Montenegro I, Pino L, Werner E, Madrid A, Espinoza L, Moreno L, Villena J, Cuellar M: Comparative study on the Larvicidal activity of drimane sesquiterpenes and nordrimane compounds against drosophila melanogaster til-til. Molecules 2013, 18(4):4192-4208.

24. Wube AA, Bucar F, Gibbons S, Asres K, Rattray L, Croft SL: Antiprotozoal activity of drimane and coloratane sesquiterpenes towards Trypanosoma brucei rhodesiense and Plasmodium falciparum in vitro. Phytother Res 2010, 24(10):1468-1472.

25. Liao F, Hu Y, Wu L, Tan H, Mo Q, Luo B, He Y, Deng J, Wei Y: the antitumor activity in vitro by 9-oxo-10, 11-dehydroageraphorone extracted from eupatorium adenophorum. Asian J Chem 2014, 26(21):7321-7323.

26. Liao F, Hu Y, Tan H, Wu L, Wang Y, Huang Y, Mo Q, Wei Y: Acaricidal activity of 9-oxo-10, 11-dehydroageraphorone extracted from Eupatorium adenophorum in vitro. Exp Parasitol 2014, 140:8-11.

27. Liao F, Wang Y, Huang Y, Mo Q, Tan H, Wei Y, Hu Y: Isolation and identification of bacteria capable of degrading euptox $A$ from Eupatorium adenophorum Spreng. Toxicon 2014, 77:87-92.

28. Fichi G, Flamini G, Giovanelli F, Otranto D, Perrucci S: Efficacy of an essential oil of Eugenia caryophyllata against Psoroptes cuniculi. Exp Parasitol 2007, 115(2):168-172.

29. Zhang L, Koyyalamudi SR, Jeong SC, Reddy N, Smith PT, Ananthan R, Longvah T: Antioxidant and immunomodulatory activities of 
polysaccharides from the roots of Sanguisorba officinalis. Int J Biol Macromol 2012, 51(5):1057-1062.

30. Glantz SA: Statistica per Discipline Biomediche. McGraw Hill; 2007

31. Nong X, Li SH, Chen FZ, Wang JH, Xie Y, Fang CL, Liu TF, He R, Gu XB, Peng $X R$ : Isolation and identification of acaricidal compounds in Eupatorium adenophorum petroleum ether extract and determination of their acaricidal activity against Psoroptes cuniculi. Vet Parasitol 2014: http://dx.doi.org/10.1016/j.vetpar.2014.1001.1002.

32. Nong $X$, Ren YJ, Wang JH, Xie Y, Fang CL, Yang DY: Clinical efficacy of botanical extracts from Eupatorium adenophorum against the Sarcoptes scabiei (Sarcoptidae: Sarcoptes) in rabbits. Vet Parasitol 2013, 195(1):157-164.

33. Deng $Y$, Shi $D$, Yin Z, Guo J, Jia R, Xu J, Song X, Lv C, Fan Q, Liang X: Acaricidal activity of petroleum ether extract of neem (Azadirachta indica) oil and its four fractions separated by column chromatography against Sarcoptes scabiei var. cuniculi larvae in vitro. Exp Parasitol 2012, 130(4):475-477.

34. Oelrichs PB, Calanasan CA, Macleod JK, Seawright AA, Ng JC: Isolation of a compound from Eupatorium adenophorum (Spreng.) [Ageratina adenophora (Spreng.)] causing hepatotoxicity in mice. Natural Toxins 1995, 3(5):350-354.

35. Kaushal V, Dawra R, Sharma O, Kurade N: Hepatotoxicity in rat induced by partially purified toxins from Eupatorium adenophorum (Ageratina adenophora). Toxicon 2001, 39(5):615-619.

\section{Submit your next manuscript to BioMed Central} and take full advantage of:

- Convenient online submission

- Thorough peer review

- No space constraints or color figure charges

- Immediate publication on acceptance

- Inclusion in PubMed, CAS, Scopus and Google Scholar

- Research which is freely available for redistribution 